\title{
Small-Gauge Colour Visions: The Role of Amateur Filmmakers in Italy's Transition from Black-and-White to Colour
}

\section{Elena Gipponi}

https://doi.org/10.15664/fcj.v0i17.2081

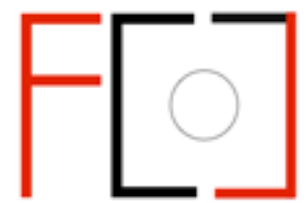

Frames Cinema Journal

ISSN 2053-8812

Issue 17 (Jun 2020)

http://www.framescinemajournal.com

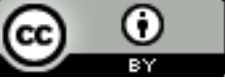




\title{
Small-Gauge Colour Visions: The Role of Amateur Filmmakers in Italy's Transition from Black-and-White to Colour
}

\author{
"One of the most powerful and dramatic changes in visual \\ rendition permitted during the past hundred years has been \\ the inclusion of color. [...] Like many other \\ "improvements" we have come to take for granted, the \\ coming of color was seen as a threat as well as a benefit." 1
}

-Neil Harris

In the field of visual studies, the chromatic regime of images is not just a perceptual or technological matter, but also an aesthetic, cultural, and political issue. This is particularly true if we look at the transition from black-and-white to colour in the history of Italy's media landscape. From a historical perspective, in the institutional setting of the Italian media system, the mass transition from monochrome images to the so-called "natural colour" images was delayed, compared to that of other European countries and the United States. Due to technological limitations and a deeply rooted cultural prejudice against colour, Italian institutional footage - by which I mean theatrically released feature films, newsreels, and television programs - was still predominantly monochrome between the 1930s and the 1960s. However, if we consider non-theatrical, small-gauge productions $(16 \mathrm{~mm}, 8 \mathrm{~mm}, 9.5 \mathrm{~mm})$, instead of the institutional, industrialised, and state-run media context $(35 \mathrm{~mm})$, the transition happened much faster.

Initially, the use of colour took hold in the amateur scene and only later became the de facto standard of mainstream $35 \mathrm{~mm}$ theatrical productions. From a strictly technological standpoint, the first effective monopack systems for subtractive colour synthesis were developed by Kodak (Kodachrome, 1935) and Agfa (Agfacolor, 1936). These film stocks are reversal emulsion systems, meaning that the negative film used for shooting is chemically converted into a projection-ready positive. ${ }^{2}$ Therefore, every movie shot on reversal film is a unique specimen, and its duplication is very difficult. Far from being an inconvenience, as the audience for home movies was relatively limited, i.e. family members, the single copy obtained through reversal film was still sufficient (and of a high enough quality) for domestic screenings. Beyond individual aesthetic preferences, small-gauge colour film stocks gained wider use in Italy during the 1950s and 1960s. At that time, the Italian amateur filmmakers that embraced colour constituted a small group of techno-enthusiasts. For them, colour was a significant improvement rather than a threat.

This article investigates the key role played by Italian amateur filmmakers in challenging and modernising the chromatic regime, by asking how was colour normalised in Italy? And what role did Italian amateur filmmakers play in this technological, aesthetic, cultural, and political transition? In order to answer these questions, this article will first trace the main stages and formal strategies adopted for the introduction of colour in different areas of the Italian culture industry: press, cinema and television. This brief overview will highlight the main theoretical and methodological issues related to the change from black-and-white to colour. The aim is to contextualise the various forms of circulation of colour images, in order to assess the familiarity of amateur filmmakers with them, and thus the relevance of small-gauge colour films in terms of a renewal of the chromatic regime. Second, it will analyse a corpus of Italian home movies in order to observe the timescale and stages of this stylistic transition and to identify some aesthetic patterns, connecting them with the coeval institutional production of still and moving images. I have traced the profile of the average Italian amateur filmmaker in the 1950s and 1960s through the analysis of a selection of private collections archived by Home Movies - Archivio Nazionale del Film di Famiglia, an Italian institution in Bologna dedicated to the preservation and valorisation of the Italian 
small-gauge film heritage. In order to reconstruct the context of production and the biographies of the amateur filmmakers I have conducted interviews with them, and in some cases with their relatives.

Considering that "Amateur activities [...] neither emerged nor evolved in a visual, social or temporal vacuum", as Heather Norris Nicholson suggests, this article will assess how Italian amateur filmmakers were fully engaged in their contemporary visual culture. ${ }^{3}$ The circulation of the same chromatic solutions among different media, and between the institutional and the amateur sphere, testifies to the nature of colour as an authentic intermedial cultural system. As Joshua Yumibe and Sarah Street have stressed in their volume on the chromatic culture of the 1920s, every given colour media product (or corpora of colour media products) must be considered in relation to its surrounding visual culture. ${ }^{4}$ Even apparently trivial products, such as colour home movies, can shed light on the transition to colour in the Italian media-scape, not as a singular and isolated event, but as a networked and multilayered process, a process driven from below and still partially unexplored.

\section{Colour and Black-and-White in the Italian Media Landscape}

For newspapers, periodicals, and magazines, the main technological innovations date back to the turn of the century and are, above all, the application of photography to printing techniques (for the creation of the matrices; the main photo-mechanical reproduction techniques are photo-engraving, photocalcography and photo-lithography) and the invention of the photographic screen to allow half-tones to be accurately printed. ${ }^{5}$ These technological innovations triggered the production of colour magazines, with full page illustrations. However, the first occurrences of colour images in journalistic publications were not photographs but illustrations and paintings, reproduced with photomechanical techniques in large print runs. While advertising, with its bright applied colours and drawings, was predictably one of the first means for the diffusion of colour in magazines another important and widespread form of circulation was indeed represented by the reproduction of famous paintings for educational purposes. In the publishing industry - as in the broader media-scape beyond print media - the first aim was to find a balance between the highbrow (colour as an element that recalls the masterpieces of art history) and the lowbrow or vernacular (colour as purely decorative). In the art reproductions, natural colour is contained in an image that combines the handcraft and the mechanical reproduction, and thus becomes a transition step between handmade illustration and photography. This is a recurring compromise, one that can be found in periodicals of very different style, from the Sunday supplements of the main national newspapers (introduced in the late Nineteenth century) to the new weekly illustrated magazines produced after the Second World War. However, moving from general-interest publications to the more technology-oriented Ferrania - a house organ monthly magazine published from 1947 to 1967 by the eponymous company, which produced black-and-white and colour film stocks for amateurs and professionals - one can find the same form of pictorial mediation of natural colour. Contrary to what might be expected, even in Ferrania, which was at the cutting edge of technology and aesthetics, colour became the standard only by the mid-1950s, after a slow process of adaptation which resorted again to art and paintings (namely, with a column devoted to the Italian Old Masters, including tipped-in colour plates). ${ }^{6}$

In regard to news, both weekly publications such as Epoca or Tempo (the Italian equivalent of Life magazine) and newsreels (such as those produced by Istituto Luce), black-and-white is dominant well into the 1960s. According to a long-standing cultural convention, in fact, a-chromatic images evoke the feeling of a journalistic objectivity. ${ }^{7}$ Even after the Second World War, newsreels remained black-andwhite. The Settimana Incom, a weekly newsreel featuring current events and gossip, produced between 1946 and 1965, was usually in black-and-white, except for some special episodes. In the latter, colour was 
perfectly suitable for an "euphorisation of the representation", as Augusto Sainati wrote, that is for creating an optimistic, sweetened image of Italian society, essentially for propagandistic aims. ${ }^{8}$

This applies to Arcobaleno italiano (Italian Rainbow), filmed in Ferraniacolor and released in 1952, coinciding with the highly successful movie Totò a colori directed by Steno (Stefano Vanzina), which was widely regarded as the first colour feature-length Italian film, also shot in Ferraniacolor. The newsreel Arcobaleno Italiano focuses on subjects and landscapes enhancing the pictorial qualities of the image, such as a picturesque village of Central Italy and a trompe l'cil painter (again, a subject connected to arts).

As for the Italian film industry, as it is often the case with technological change, the large-scale adoption of colour was advanced by popular films rather than arthouse productions. ${ }^{9}$ In Italy, indeed, the theatrical production of colour films in the 1950s and 1960s was concerned with certain popular genres such as sword-and-sandal films, horror and comedy (like the already mentioned Totò a colori). On the other hand, established directors such as Federico Fellini or Michelangelo Antonioni embraced colour only in the mid-Sixties with Juliet of the Spirits (1965) and Red Desert (1964) respectively.

However, the use of colour was not pioneered by mass-market films, but by genres such as documentary and animation, especially in short form. ${ }^{10}$ In the field of documentary, particularly between 1945 and 1955, hundreds of debut films and other titles were produced, especially with regard to the subgenres of tourism films, ethnographic or exotic films and documentaries on painters or sculptors. The rationale behind many of these productions was usually related to marketing, art appreciation or ethnography.

Another crucial element is television. It took twenty-three years for Italian public TV to embrace colour. The first programme in colour was aired on February 1st, 1977 (black-and-white programmes were airing in Italy since 1954). ${ }^{11}$ This late transition became a hot button issue in Italy, considering that most technologically advanced countries reached this milestone at least a decade earlier. ${ }^{12}$ This delay however, is due more to cultural than technological reasons, and it is generally considered a political issue motivated by biases and prejudices. Indeed, the intense economic development (the so-called "boom") that affected Italy between the 1950s and the 1960s determined a tumultuous growth of private consumption of durables (cars, refrigerators). The manufacturing companies of television sets were experimenting from the 1960s, in cooperation with Rai (Radio Televisione Italiana, the national television broadcasting company), on the transmission of colour signals, and were pushing towards the adoption of this technology and the substitution of the old black-and-white TV sets with the new ones. The government, however, issued some measures in order to restrict individual expenses and encouraged public and social investments, because according to the main political parties and the labour unions colour TV sets were an unnecessary luxury in a country that was lacking the main social services. ${ }^{13}$ Furthermore, the new colour commercials were considered dangerous in so far as they could have been too tempting, thus encouraging those expenses that the measures against consumerism wanted to restrict. ${ }^{14}$ Ultimately then, the very same symbolic dichotomy - realism/phantasmagoria - accompanying the introduction of colour in other media applies to TV as well. As a matter of fact, in the Western world precise cultural meanings have been attributed to colour images; meanings that can be summarised in the double register of the authentic documentation, on the one hand, and of the fantastical on the other hand. Compared to black-and-white images - both still or moving - colour images seem closer to the "real thing", "transparent", and less mediated. Conversely, if compared to black-and-white images, they appear somehow "fictional", artificial. ${ }^{15}$

This overview of the Italian publishing industry, of news and newsreels, commercial cinema and television allows us to individuate the circulation and the uses of natural colour between the 1930s and the 1960s, in a media environment still dominated by black-and-white images. It represents the context in which the Italian amateur filmmakers built their average 'colour images literacy' in the abovementioned 
time-span. This literacy - especially for those, like amateurs, who make images without a professional background - is not built only on intentional and "self-aware" media consumption (e.g. the films watched in movie theatres), but also on all the accidental, distracted views of everyday situations: newsreels or documentaries screened before the films, printed magazines, televisual images. The work of Italian amateur filmmakers that I am going to analyse in the next section of this article draw fully, but with different degrees of awareness, from this iconographic repertoire.

\section{Colour in Amateur Filmmaking Practices}

Between the 1950s and the 1960s, in a country still stuck in its pre-industrial phase, even in the years of the economic "boom" (conventionally 1958-1963), amateur filmmakers represented an élite of people with an inquiring mind, who were irresistibly attracted by "the new" - especially by technological novelties. In order to analyse how the Italian amateur filmmakers use colour film stocks in their home movies, this article will first consider them as a collective and anonymous subject (on the basis of the sample mentioned in the introduction), and then proceed with a close analysis of individual case studies with their own names and identities, in order to highlight the heterogeneity and the complexity of the phenomenon.

According to the main scholarly works on the subject, the typical Italian amateur filmmaker in the 1950s and 1960s was a wealthy individual, who had a highly specialised technical job (there are numerous engineers; as for women, female amateurs usually are not housewives, but they have a job outside their homes). ${ }^{16}$ Before devoting themselves to small-gauge cinema, almost all the amateurs surveyed for this research were also amateur photographers, for whom the possibility of recording movement was considered an improvement. They all shared the necessity to film in the right way and a negative judgement towards wrong images - like a chaotic or shaky tracking shot, backlit or blurred images - thus demonstrating a good average level of knowledge of the cinematic language. At the same time, there was a sort of spontaneous agreement about what makes a colour image good, as taught in the howto literature on this topic. The good colour image should be shot with a correct camera aperture and and harmonious composition of the hues within the frame. ${ }^{17}$ However, besides the single aesthetic results, what is worth noting is that there was a unanimous acceptance of colour images, which were considered better than black-and-white ones because they were perceived as "more modern", regardless of any aesthetic and social implications.

For a male or female amateur filmmaker of the 1950s and 1960s, indeed, colour was already natural, because it was one of the emerging features of their visual present. Conversely, black-and-white was a visual quality of the cinematic forms of their past, in particular of the 1930s and the 1940s, the only period in which film images were for the majority achromatic (with no hand-colouring, toning, tinting or sepia, just a "pure" black-and-white). Using colour film stocks, these amateur filmmakers demonstrate the fact that they belong to a specific social and historical context, that of modernity. ${ }^{18}$

I will now focus on private collections of amateur films, in order to individuate the most common uses of colour images in home movies, as well as to understand which relationship these works establish with the coeval "institutional" media production and with the main strategies of assimilation of colour film technologies.

First of all, like in the majority of theatrical, mainstream films, in several amateur films colours are taken for granted because of their omnipresence. ${ }^{19}$ They work as a sort of neutral background that nonetheless is often the subject of the image; everything is in colour, so colours are not seen and perceived as a relevant visual feature of these images. By way of example, one could mention the numerous films of landscapes, particularly of vacation spots, in which the amateur filmmakers film extreme-long and long shots - without any visible human subject - of coasts and slopes, that are 
enlivened by slow, controlled tracking movements. In these filmed fragments, especially compared to similar establishing tracking shots in black-and-white, the loss of depth of field is truly evident. In some moments, the camera almost seems to explore a two-dimensional backcloth barely ruffled, a papier-mâché bas-relief. In this way, the "realistic" use of natural colour is redirected towards an imaginary of oleographic, glossy landscapes that seem to have only a feeble connection with the reality they should record.

Extremely popular among the amateurs, this postcard-like use of colour film can be attributed to the aesthetic of those documentary short films mentioned above, unmercifully described by Federico Pierotti as "a random juxtaposition of photographic postcards, ruled sometimes by poor taste, some other times by a flat, oleographic sensitivity". ${ }^{20}$ This definition can apply both to the colour documentaries and to the home movies of the same years. In fact, if we consider the home movies as an offspring from the family album, the metaphor of the postcard is even more appropriate. The tracking shots of sea or mountain landscapes that so often appear in the private home movie collections of those years are, as a matter of fact, precisely landscape photographs or postcards just slightly animated.

The correspondence between the Italian colour documentary of the post-war era and the home movies shot in colour concerns also the choice of subjects. The fountains in Rome, for example, constitute a real subgenre in itself (called "romano") in the institutional documentary catalogues. ${ }^{21}$ Water fountains are frequently filmed by amateurs, who also like to edit together all the sequences dedicated to the capital's fountains. The postcard, furthermore, is not just a metaphor, but a literal insert in many films, especially in the subgenres of holiday or travel movies. A recurring visual solution is indeed represented by the insertion, at the beginning of the film, of the shot of a real postcard, or of the front cover of a travel guide, or of a page from an illustrated brochure. Usually this opening shot has, in the pro-filmic sense, writing that indicates the name of the place, which thus can work as the title of the film.

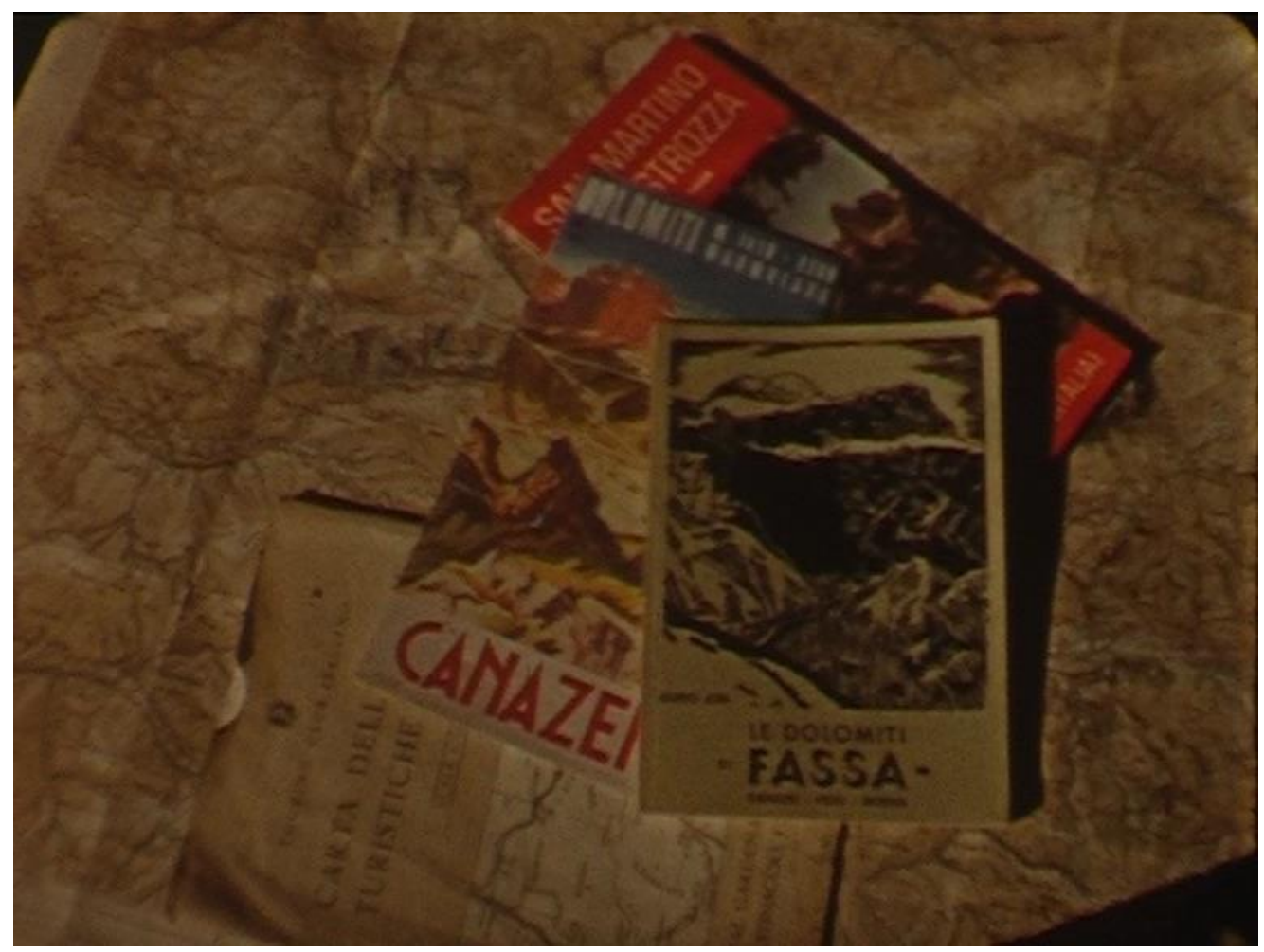

Figure 1: Pietro Tade' collection, reel 3, 1958, 8mm. Courtesy Home Movies - Archivio Nazionale del Film di Famiglia, Bologna. 


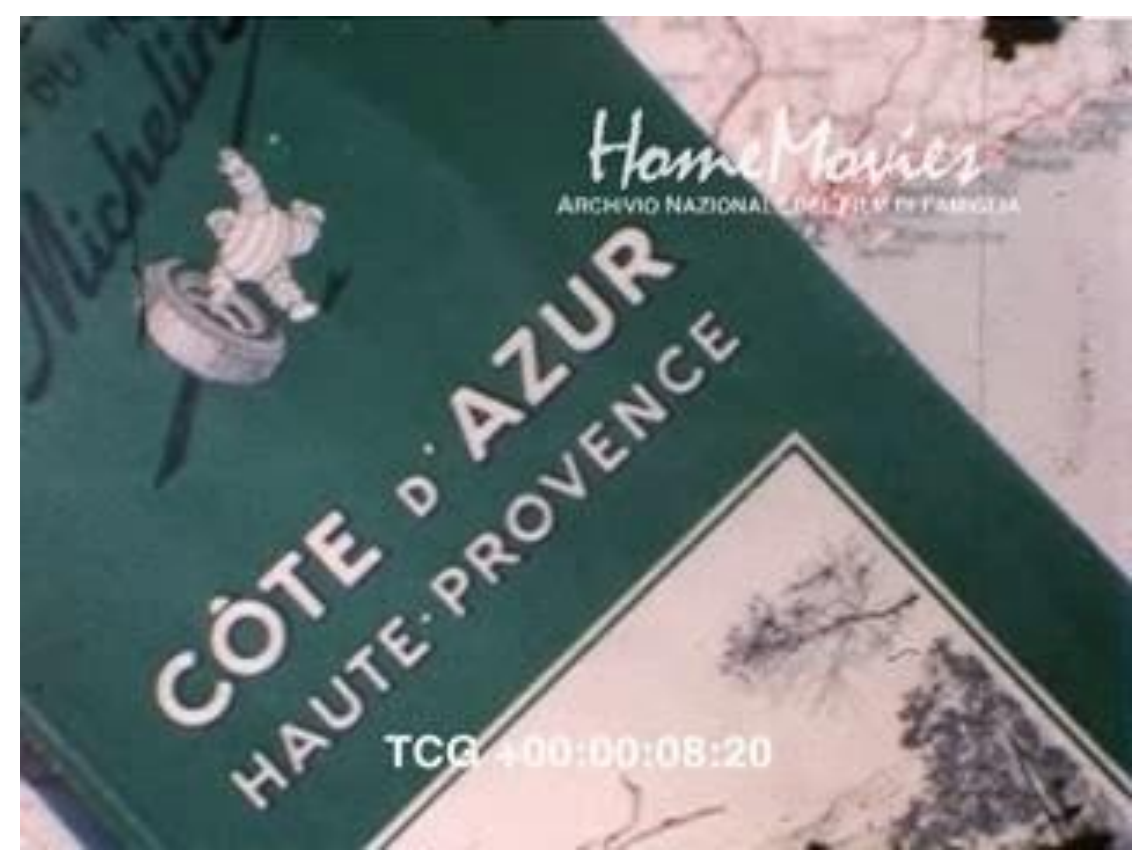

Figure 2: Mantovani collection, reel 7, 1959, 8mm. Courtesy Home Movies - Archivio Nazionale del Film di Famiglia, Bologna.

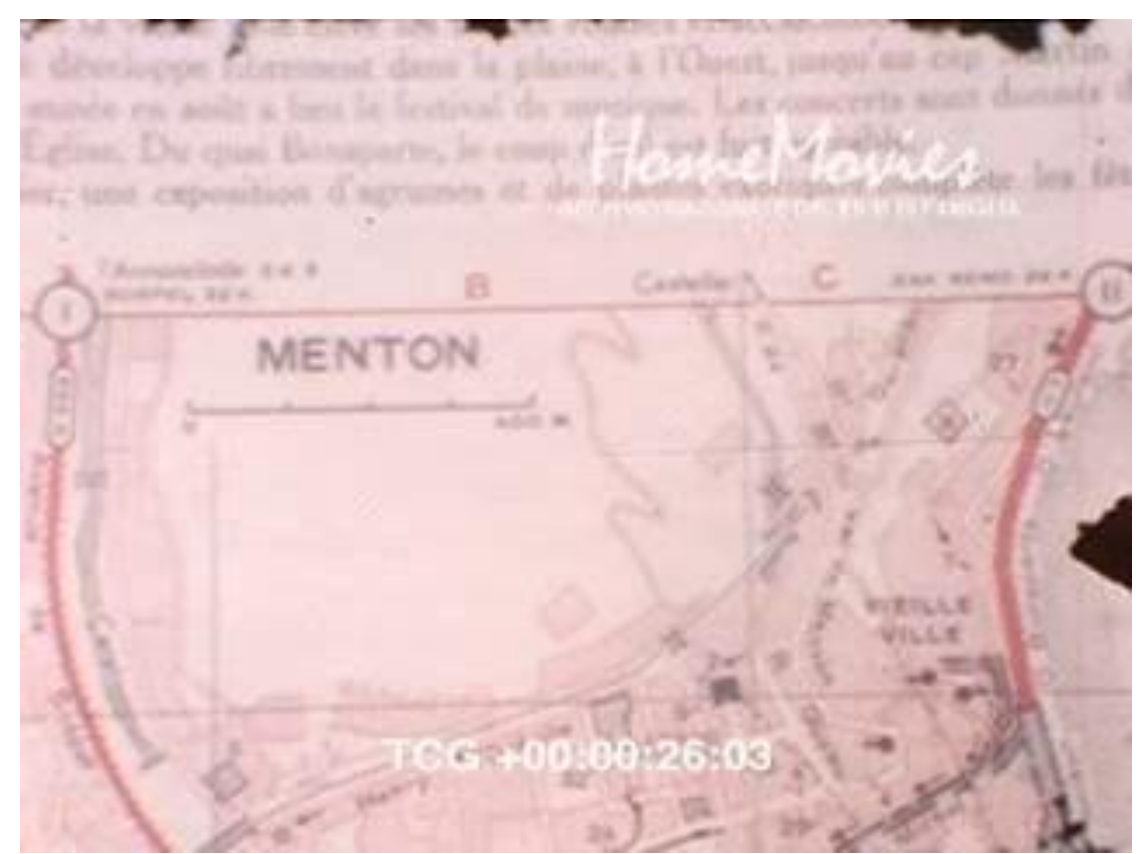

Figure 3: Mantovani collection, reel 7, 1959, 8mm. Courtesy Home Movies - Archivio Nazionale del Film di Famiglia, Bologna.

The pages of the travel guides or of museum catalogues, however, are not just used as opening shots, but are also shown in the middle of the films, as if they were "second hand" inserts that are intercut with the shots of the real "live" places, monuments and buildings visited. This use of still images is present in the collection of the engineer Carlo Fuzzi, which includes numerous didactic and educational documentaries (rather than holiday home movies). These are shot in many important archaeological sites, with the addition, in postproduction, of a voice-over commentary written and read by the amateur's first wife, Laura, a graduate in literature and an archaeology enthusiast - the majority of their documentaries, indeed, open with the caption "Carlo and Laura Fuzzi present". Some of their titles, entirely shot in colour, are: Volti d'Etruria (Etrurian Faces, reel 1), Viaggio magico (Magic Journey, reel 4, in the Sicilian former colonies of the Magna Grecia), Pompei (reel 7), Lecce Fiore Barocco (Lecce, Baroque Flower, reel 9), Le ville di 
Tivoli (Tivoli's Villas, reel 10), all documenting journeys that the couple had carefully planned thanks to travel guides and historical volumes. ${ }^{22}$

Another subgenre of this collection - again in colour - consists of the development of a topic using famous paintings. Il banchetto (The Banquet, reel 5), for example, is a sort of pamphlet on the value of having dinner together at the table. The film shows paintings from various ages, all representing banquets and convivial scenes. Laura's voice over, in the opening, recites "This journey through time and arts wants to be a protest against canned food and conventional, hurried meals..."

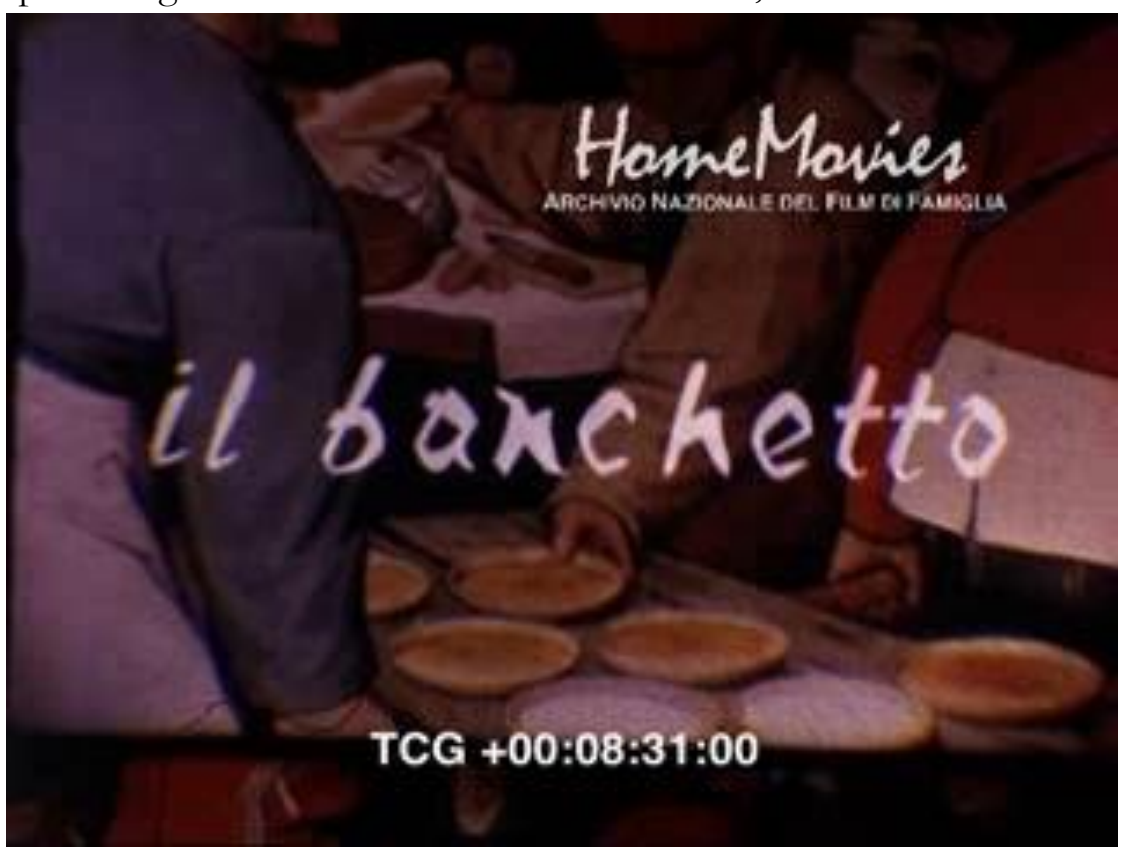

Figure 4: Carlo Fuzzi collection, reel 5, 196?, 8mm. Courtesy Home Movies - Archivio Nazionale del Film di Famiglia, Bologna.

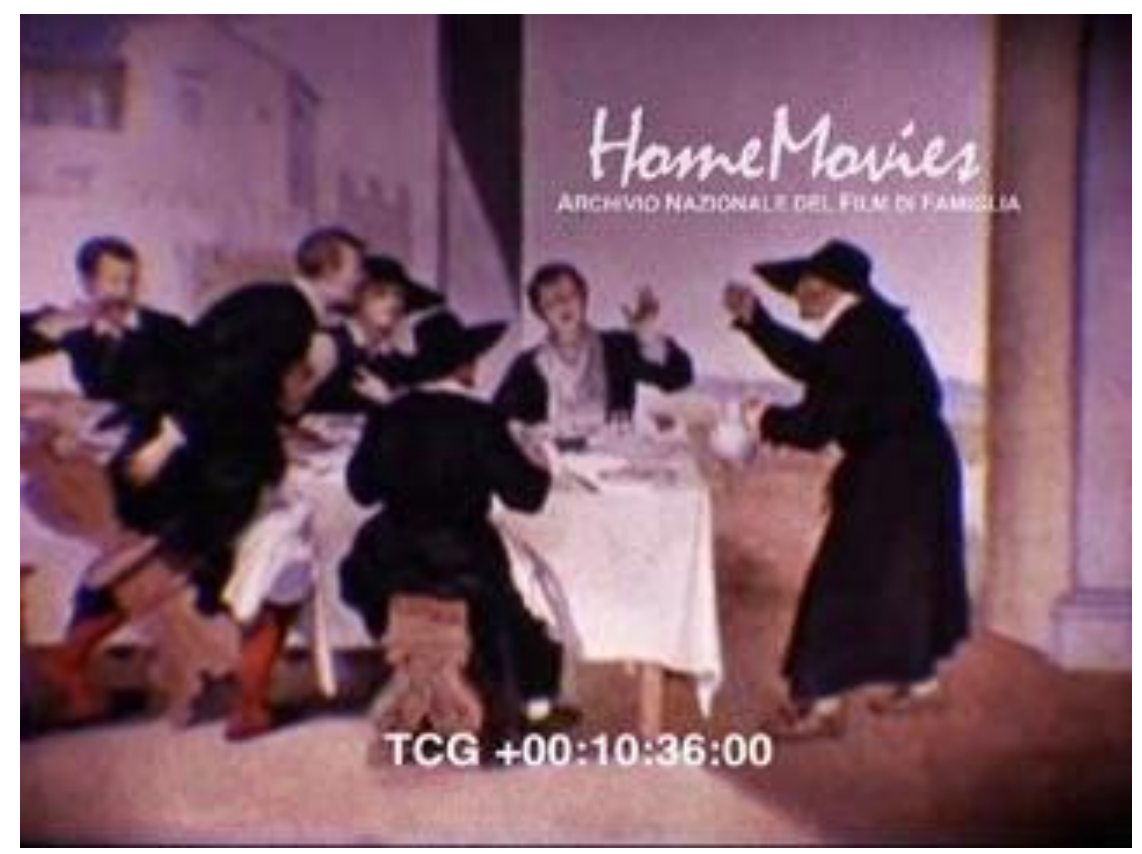

Figure 5: Carlo Fuzzi collection, reel 5, 196?, 8mm. Courtesy Home Movies - Archivio Nazionale del Film di Famiglia, Bologna.

The same thematic principle is adopted for Le stagioni (Seasons, reel 22), in which the four seasons are presented using the masterpieces of the macchiaioli. The images of art masterpieces are often shot "live", that is, "stolen" from museums and exhibitions, while in some other cases Fuzzi filmed (with 
many zooms in and out) the photographs of the paintings reproduced in catalogues and art history books. ${ }^{23}$ Therefore, also in this case there is the mediation between the natural colour of the Kodachrome film and the applied, hand colouring of the works of art, a strategy similar to the one adopted by illustrated magazines, which negotiate the introduction of colour using photographs of works of art and tipped-in colour plates.

Together with the highbrow images of the art masterpieces, the other influences in the amateur films of the 1950s and the 1960s are drawings and illustrations taken from popular sources, such as children books, comics, animated films, posters, with a playful use of colour that reflects the many festive occasions and the colourful ceremonies that are represented in the home movies. In this respect, the amateur production of Emilio Grimaldi is truly representative of the most common strategies in the use of colour in amateur cinema. Emilio Grimaldi was of a military background - first an official, and then a colonel of the cavalry. Often combined with the making of photo albums, his $8 \mathrm{~mm}$ cinematic production, both in black-and-white and in colour, spans intermittently twenty-five years, from the end of the 1930s to the first half of the 1960s. Amateur filmmaking practice for him constituted an ideal point of convergence of his many interests and, like Fuzzi, he pushed his practice towards "heretical" uses, different from the most common amateur productions. The images devoted to his family are sporadic, and they are just labelled as Casalingherie (Domestic Stuff) and stored a bit haphazardly as random, unedited fragments. The other films, however, really show an expert use of the camera and of colour, and thus make this collection emblematic.

Reel number 10, for example, is a film "on Martians", dated 1960 and entirely shot in colour. In the years of the space frenzy (the opening caption reads "February of the Earth year MCMLX") Grimaldi invents the peculiar figure of a yellow Martian, very similar to a chicken, with a beak and a pointy crest, that is going to attack the Earth - or more precisely Pinerolo, the small village in which Grimaldi lives. The opening of the film shows a painted backcloth that depicts the sidereal space, the extra-terrestrial planet and the chicken-alien, a hand animated cardboard cut-out that, with its giant telescope, individuates its target. 


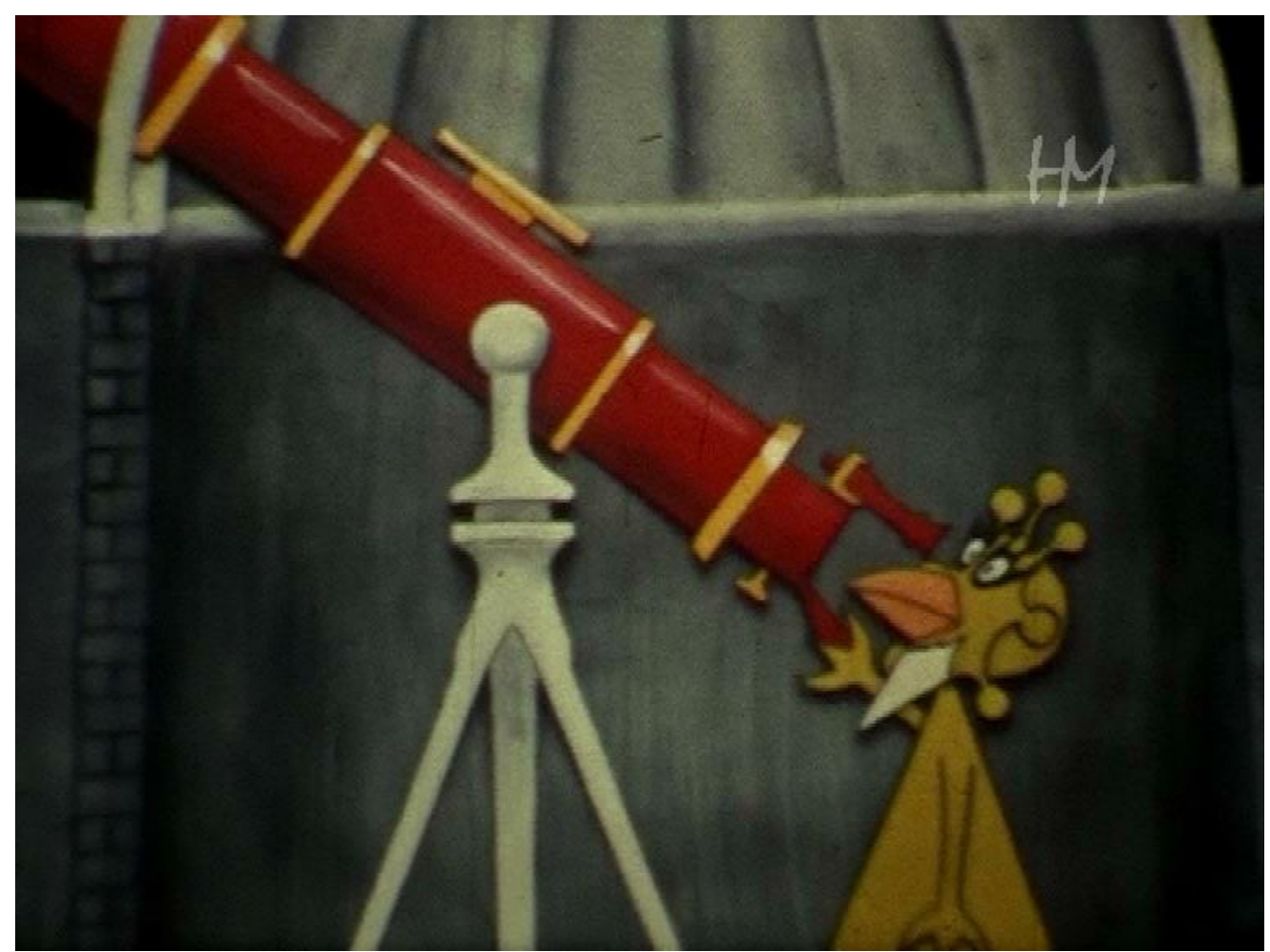

Figure 6: Emilio Grimaldi collection, reel 10, 1960, 8mm. Courtesy Home Movies - Archivio Nazionale del Film di Famiglia, Bologna.

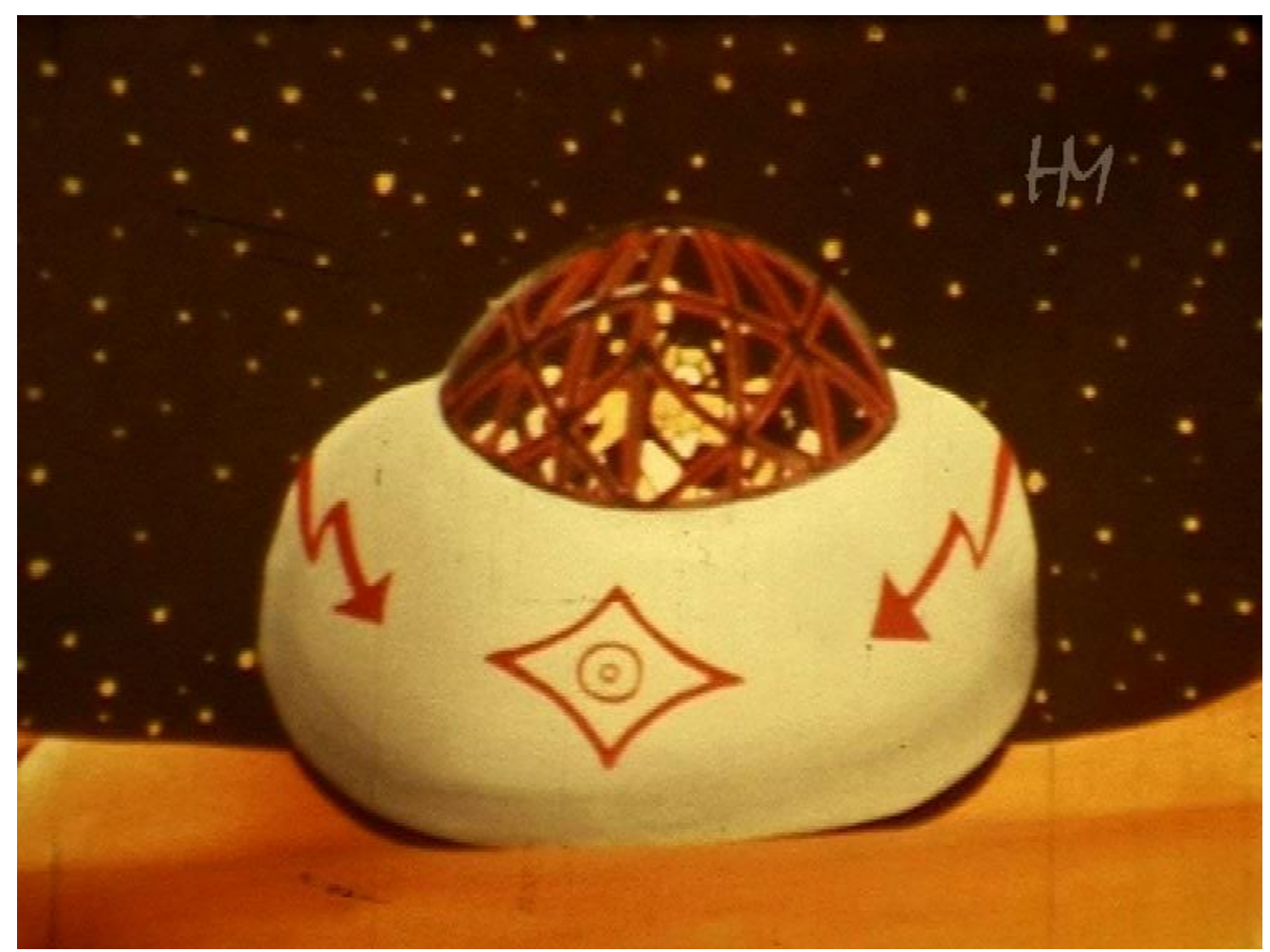

Figure 7: Emilio Grimaldi collection, reel 10, 1960, 8mm. Courtesy Home Movies - Archivio Nazionale del Film di Famiglia, Bologna. 


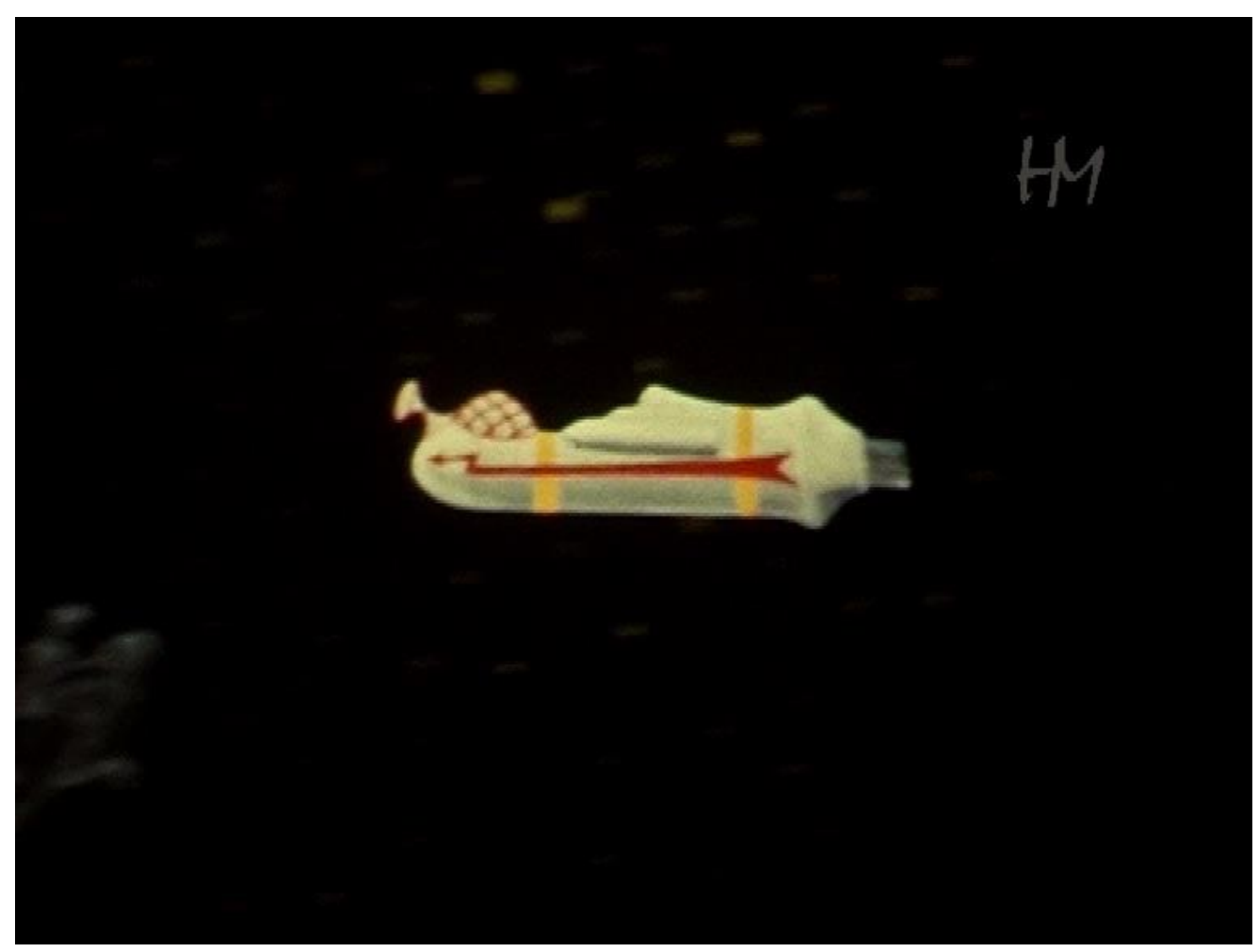

Figure 8: Emilio Grimaldi collection, reel 10, 1960, 8mm. Courtesy Home Movies - Archivio Nazionale del Film di Famiglia, Bologna.

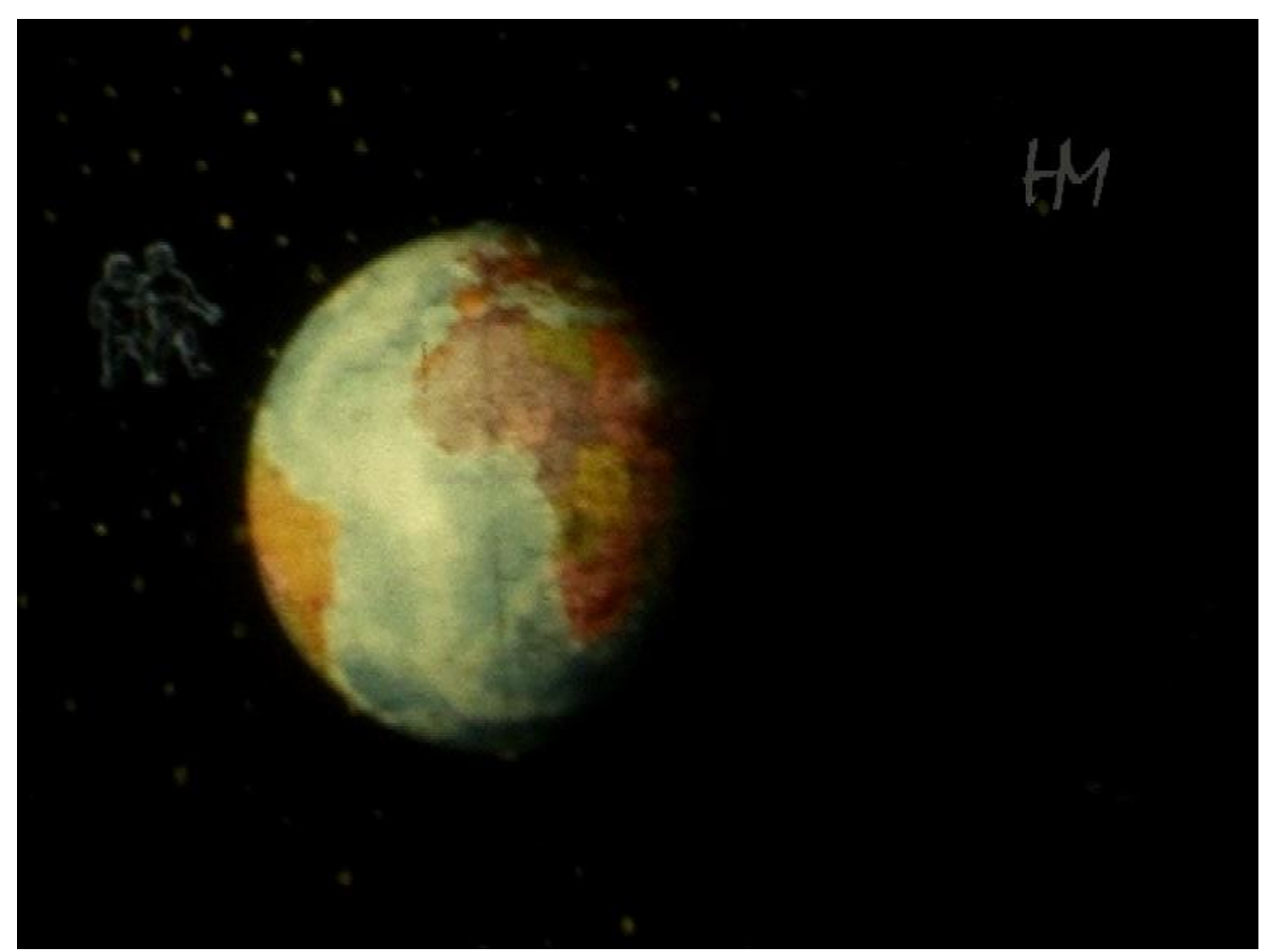

Figure 9: Emilio Grimaldi collection, reel 10, 1960, 8mm. Courtesy Home Movies - Archivio Nazionale del Film di Famiglia, Bologna. 


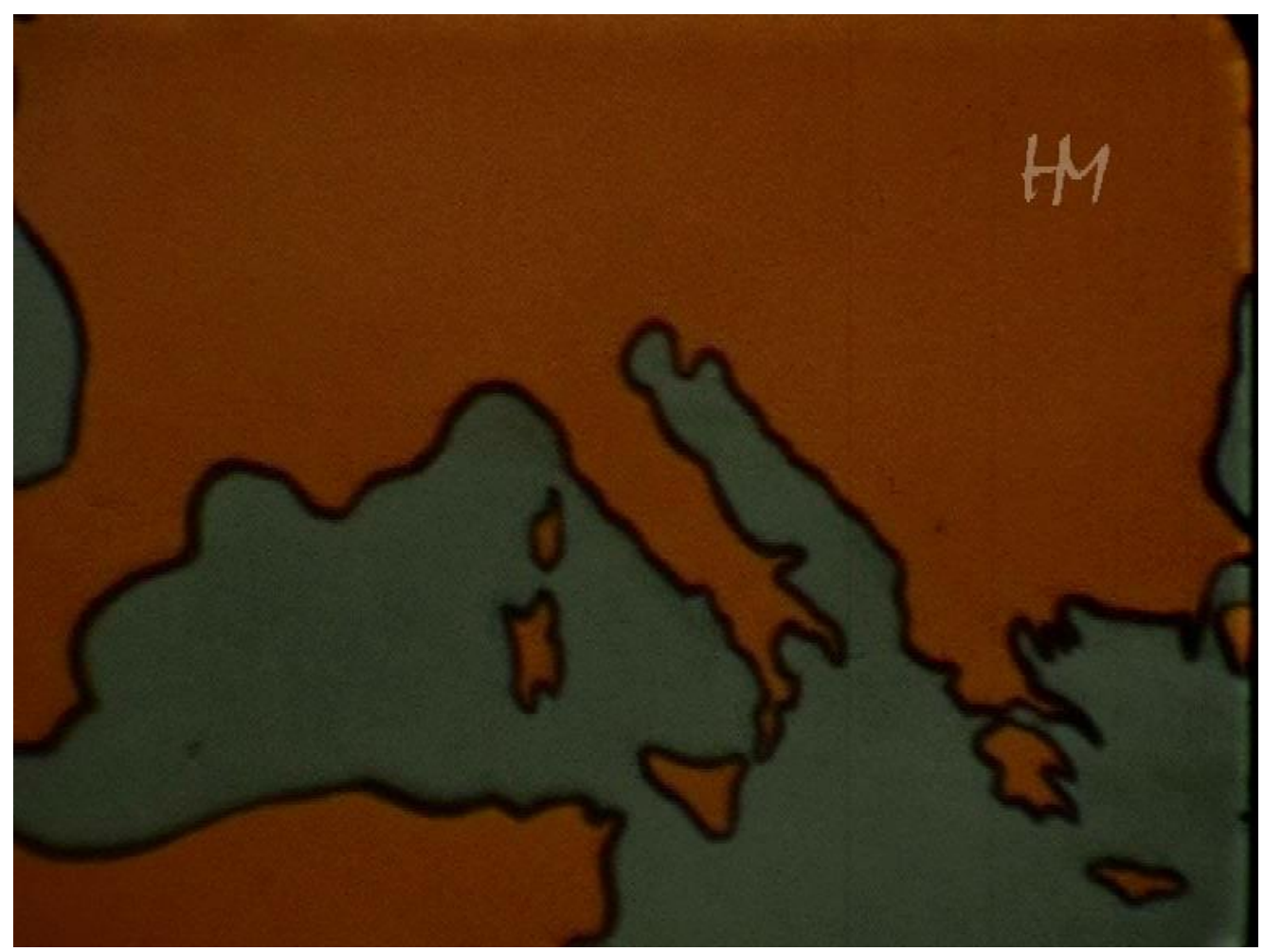

Figure 10: Emilio Grimaldi collection, reel 10, 1960, 8mm. Courtesy Home Movies - Archivio Nazionale del Film di Famiglia, Bologna.

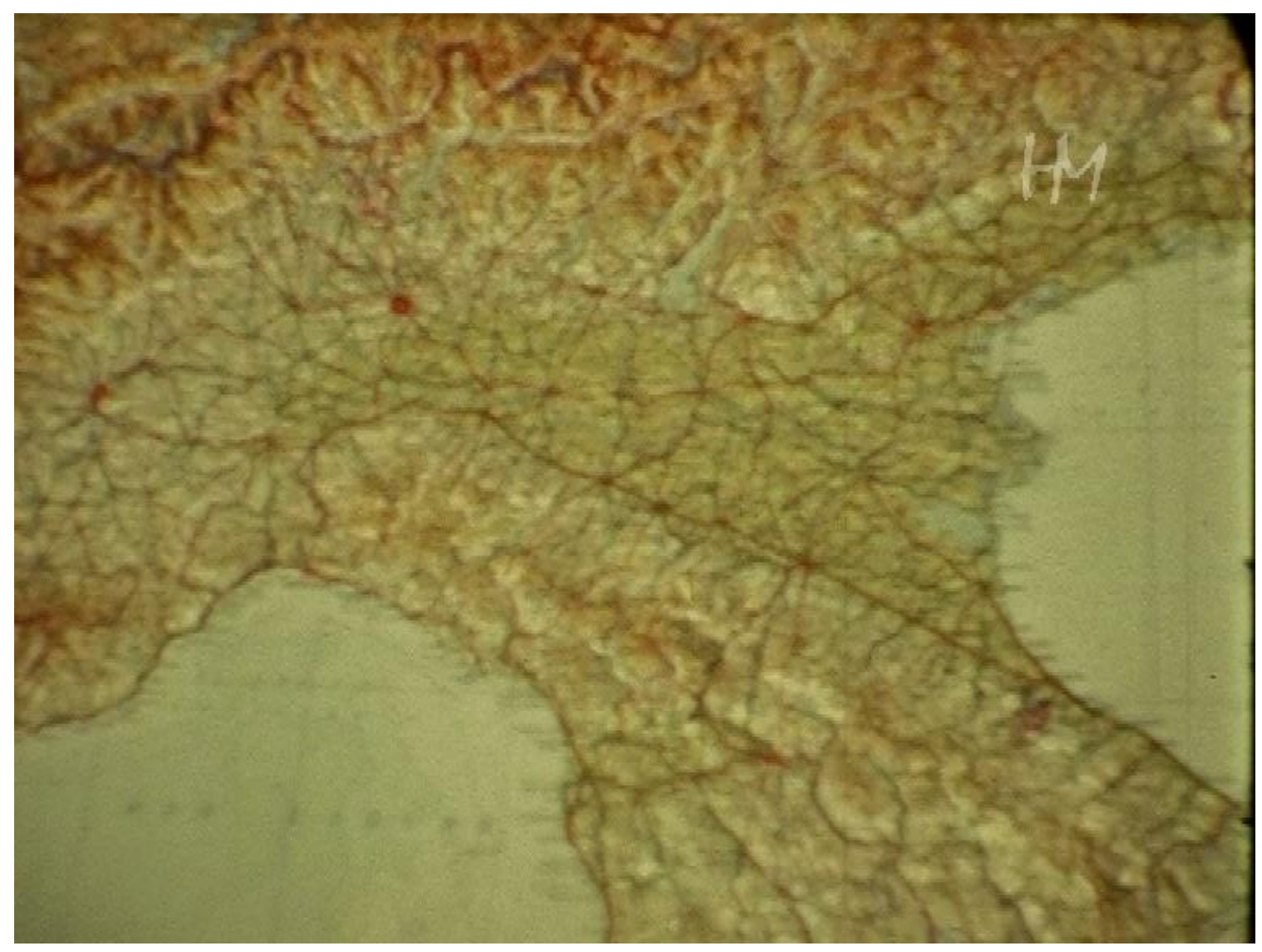

Figure 11: Emilio Grimaldi collection, reel 10, 1960, 8mm. Courtesy Home Movies - Archivio Nazionale del Film di Famiglia, Bologna. 


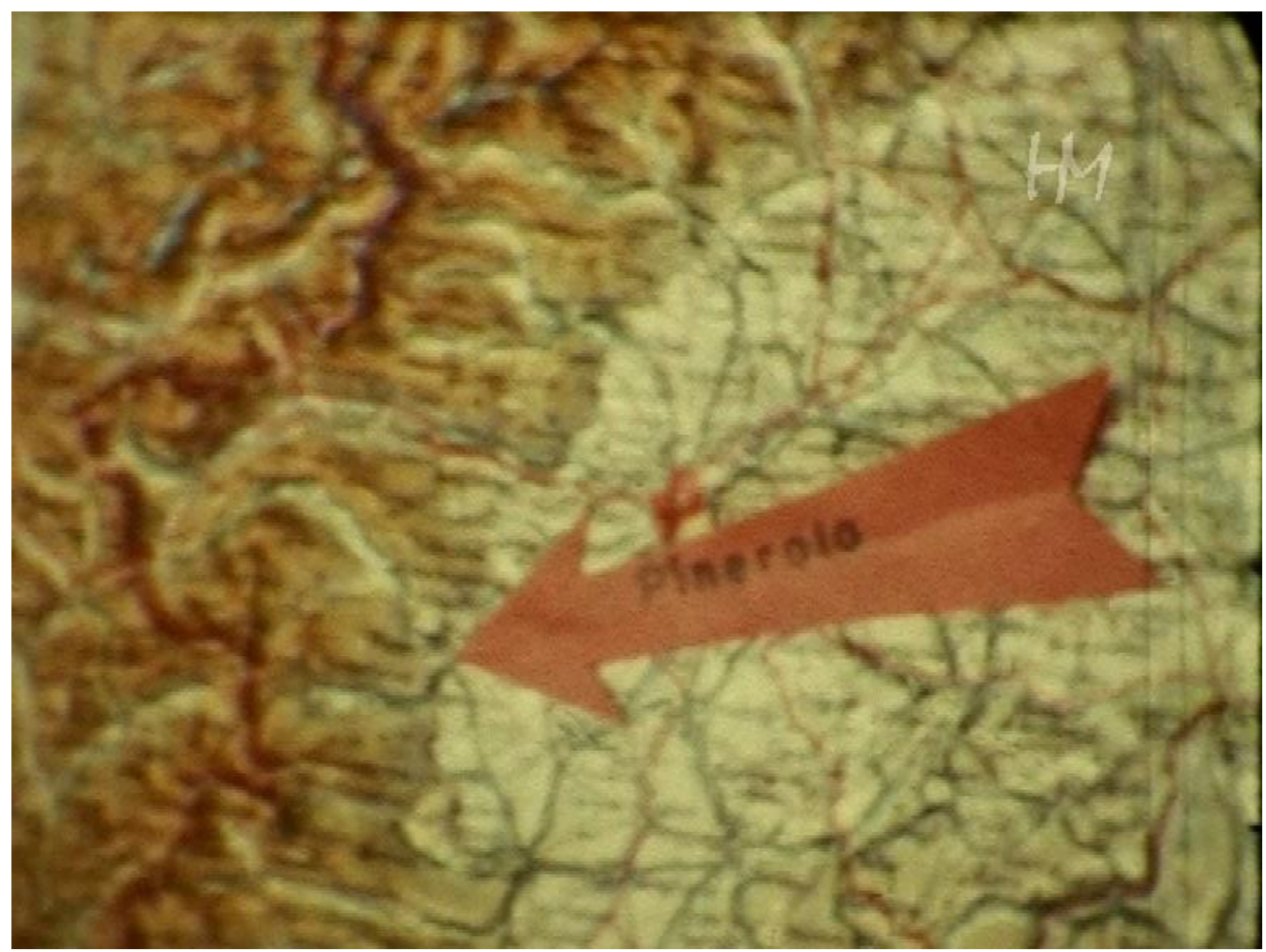

Figure 12: Emilio Grimaldi collection, reel 10, 1960, 8mm. Courtesy Home Movies - Archivio Nazionale del Film di Famiglia, Bologna.

The attack scene is made by live action shots in which, to the aid of the terrified inhabitants of Pinerolo, rushes no less than the cavalry! Colonel Grimaldi takes advantage of his role in order to ensure the presence of some trucks and army tanks, obtaining a truly spectacular effect (as in many war movies, the camera at some point shoots from below, thus making the vehicles look even more majestic).

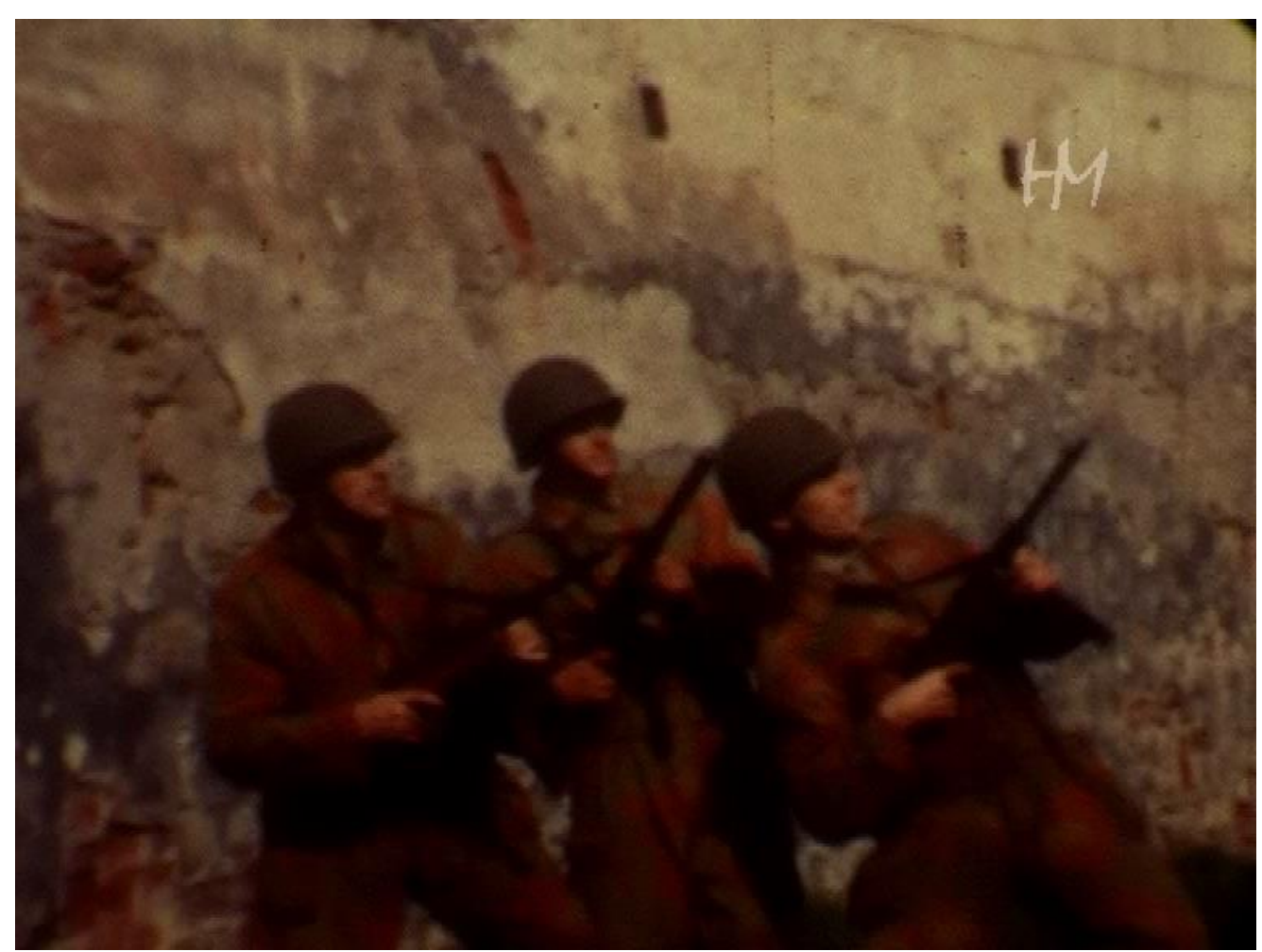

Figure 13: Emilio Grimaldi collection, reel 10, 1960, 8mm. Courtesy Home Movies - Archivio Nazionale del Film di Famiglia, Bologna. 


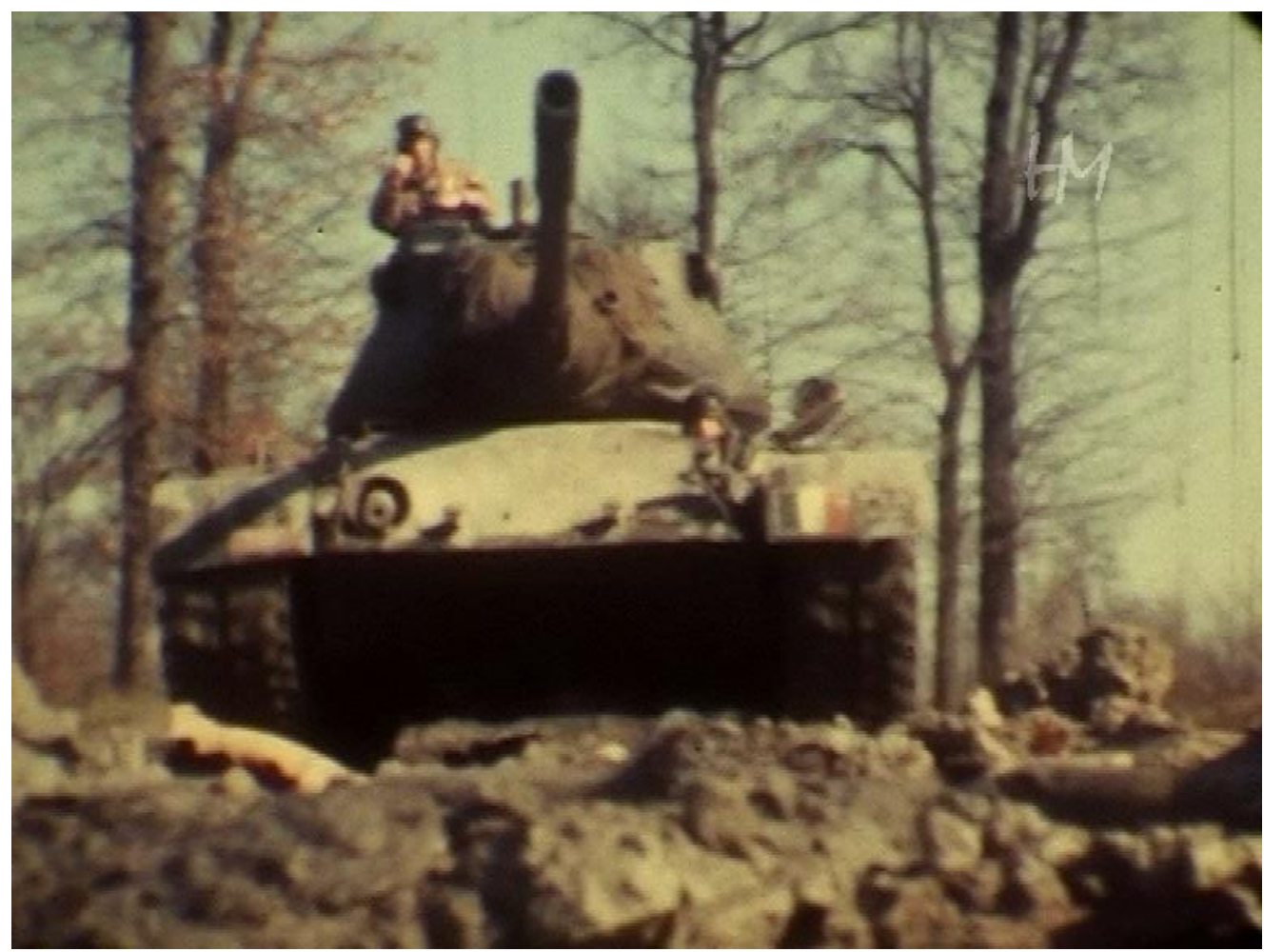

Figure 14: Emilio Grimaldi collection, reel 10, 1960, 8mm. Courtesy Home Movies - Archivio Nazionale del Film di Famiglia, Bologna.

And then, at the climax, as if we were waking up from a nightmare, the caption "It's Carnival!" appears, and the film goes on documenting a parade of carnival floats, one of which is a spaceship full of chickenMartians.

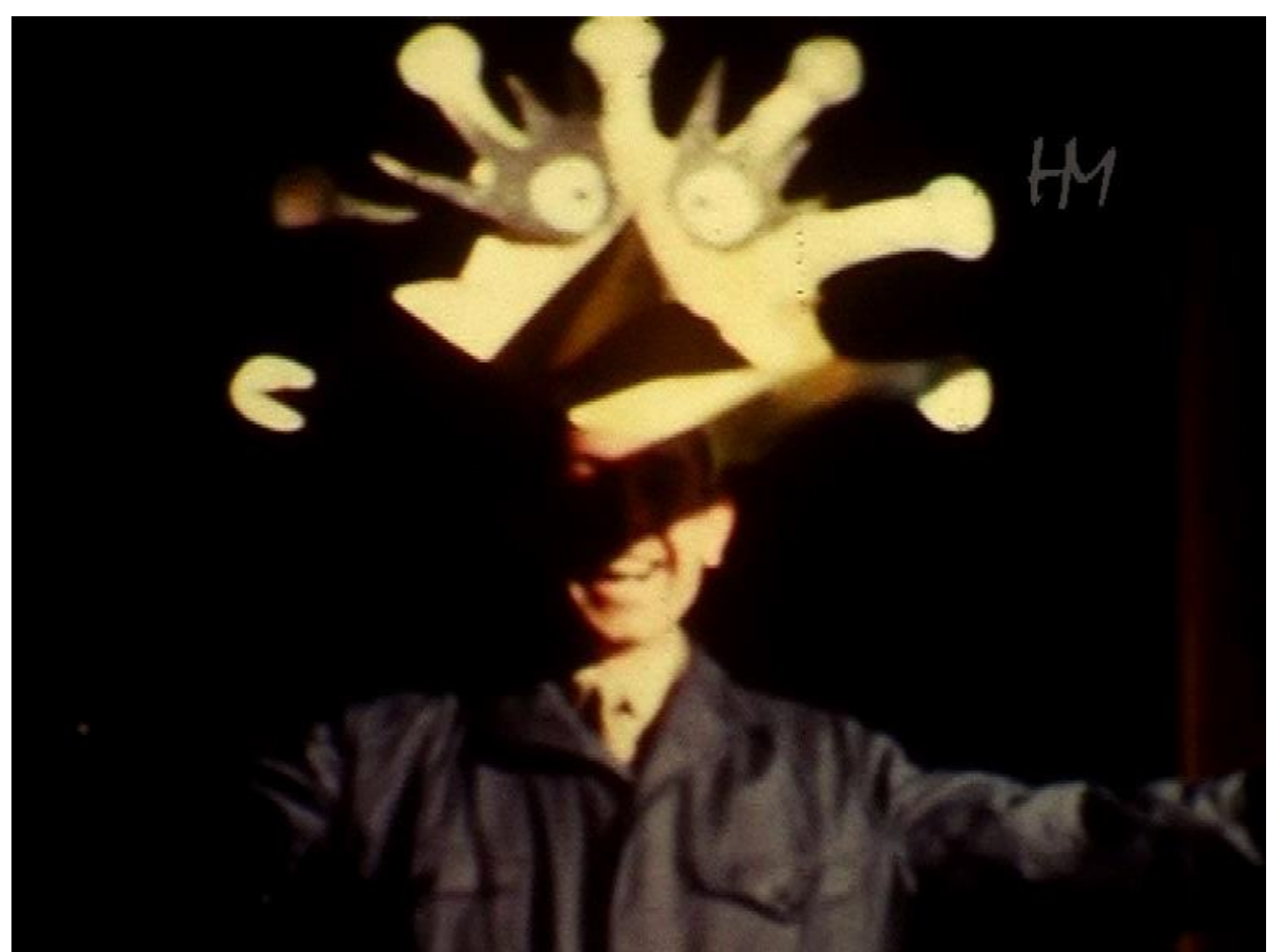

Figure 15: Emilio Grimaldi collection, reel 10, 1960, 8mm. Courtesy Home Movies - Archivio Nazionale del Film di Famiglia, Bologna. 


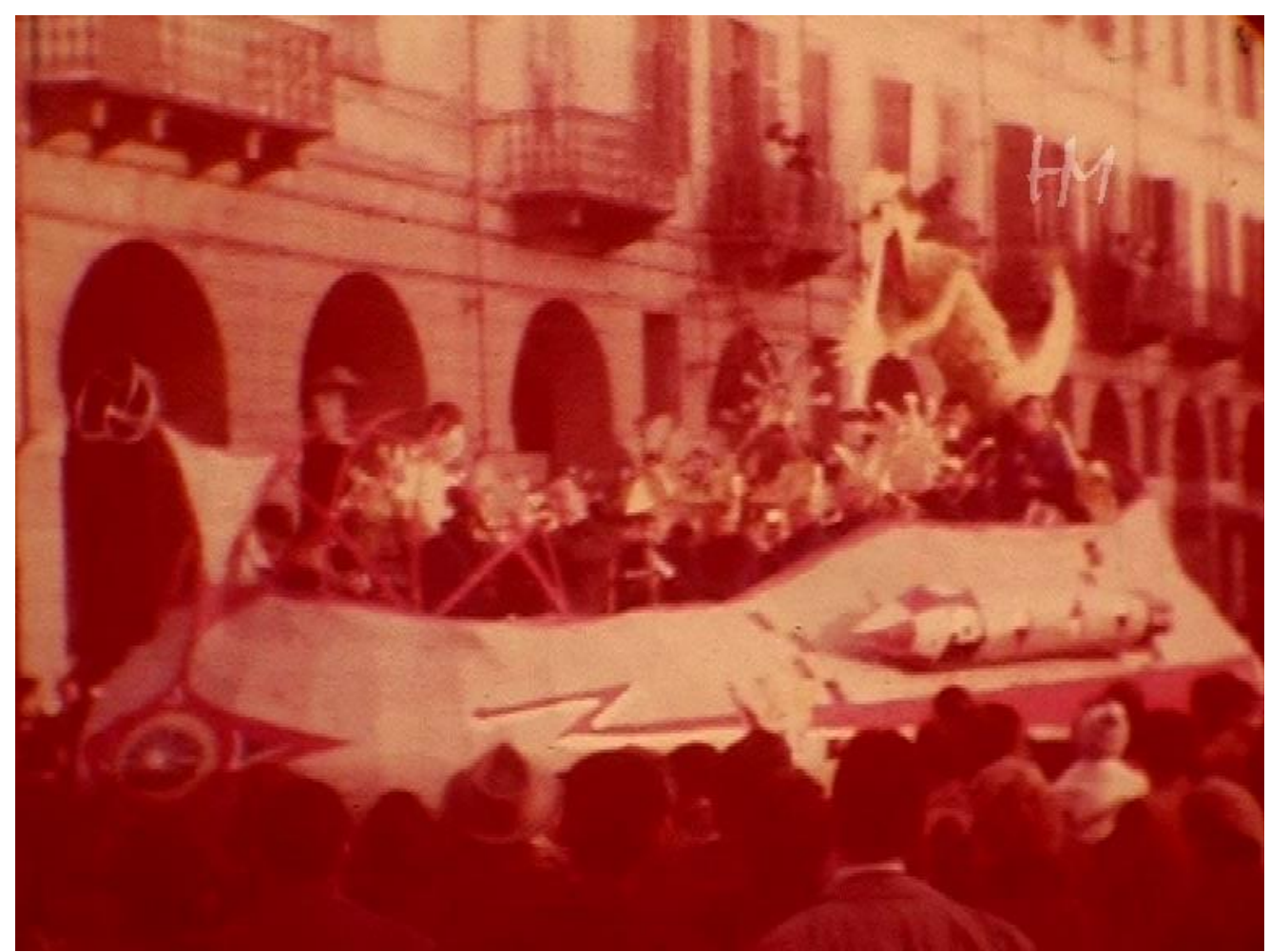

Figure 16: Emilio Grimaldi collection, reel 10, 1960, 8mm. Courtesy Home Movies - Archivio Nazionale del Film di Famiglia, Bologna.

The film, therefore, is a sort of second-degree narration, inserted over a pre-existing staging activity in which the amateur filmmaker participated (that is, the design of the float and of the Martians' costumes for the Carnival parade). Even though this cannot be considered an animated film (the drawings are part of the pro-filmic, and there is no stop motion animation), the transition from a hand-painted image (usually painted by the amateur filmmaker) and its "embodiment" in a live shot is not just the synthesis of the poetic personality of Grimaldi, but more broadly another form of mediation, frequent in smallgauge cinema, between applied, artificial colour (usually used for titles and captions) and natural/photographic colour.

Emilio Grimaldi, Carlo Fuzzi (a painting, music and archaeology buff) and the other amateur filmmakers I encountered were, often unconsciously, the true evangelists or, at least, ambassadors of colour. They, indeed, were also spectators, as outlined by Valérie Vignaux and Benoit Turquety in a recent study on amateur cinema. ${ }^{24}$ The amateurs filmmakers' media literacy is not just built through theatrical screenings, but above all through other forms of image consumption, maybe less organised and more often "accidental". ${ }^{25}$ The chromatic solutions adopted, in particular, recall more or less consciously the forms of circulation of colour in many popular and lowbrow media products, such as documentaries, colour newsreels, illustrated magazines. The analysis of the way in which colour is used in the home movies demonstrates that the model is not represented by institutional cinema, but by other kinds of images, other stages, forms and histories of the images, attributable to a longstanding tradition of popular art forms (or to popular forms of diversion from the "main" artistic production).

As Richard Misek writes, "Cinema's transition to color was the sum of innumerable transitions to color [...], a transition that [...] remains perpetually incomplete." ${ }^{26}$ According to Misek, the transition to colour is actually a "network of transitions". ${ }^{27}$ This is especially true for the Italian media context, where the transition to colour remains perpetually incomplete and configures itself as a layered network of transitions. A crucial layer of this network is constituted by the anonymous mass of amateurs, a small 
army of pioneers, who were very important to the social diffusion of mechanically reproduced colour in moving images.

To conclude, approaching the transition to colour in the Italian media-scape through amateur cinema may be productive, more generally, in order to conceive colour as an authentic intermedial cultural system, circulating not only "on the surface", in the institutional, theatrical, state-run media, but also and especially in an underground way, in the most overlooked and apparently uninteresting areas of iconic production, where intermediality is particularly emphasised.

*Translated from the Italian by Chiara Grizzaffi. A special thanks to Matteo Bittanti for his final reading.

${ }_{1}^{1}$ Neil Harris, Cultural Excursions: Marketing Appetites and Cultural Tastes in Modern America (Chicago-London: University of Chicago Press, 1990), 9.

${ }^{2}$ On the main principles of the subtractive system and on monopack technology see Steve Neale, Cinema and Technology: Image, Sound, Colour (London: Basingstoke-Macmillan Education, 1985), 110-111 and Leo Enticknap, Moving Image Technology: From Zoetrope to Digital (London-New York: Wallflower Press, 2005).

${ }^{3}$ Heather Norris Nicholson, Amateur Film. Meaning and Practice 1927-77 (Manchester-New York: Manchester University Press, 2012), 18. The recent scholarship on amateur cinema includes Laura Rascaroli and Gwenda Young with Barry Monahan, eds, Amateur Filmmaking. The Home Movie, the Archive, the Web (New York-London: Bloomsbury 2014); Ryan Shand and Ian Craven, eds, Small-Gange Storytelling. Discovering the Amateur Fiction Film (Edinburgh: Edinburgh University Press: 2013); Charles Tepperman, Amateur Cinema. The Rise of North American Moviemaking, 1923-1950 (Oakland: University of California Press, 2015); Susan Aasman, Andreas Fickers and Joseph Wachelder, eds, Materializing Memories. Dispositifs, Generations, Amateurs (New York-London: Bloomsbury 2018); Annamaria Motrescu-Mayes and Heather Norris Nicholson, British Women Amateur Filmmakers. National Memories and Global Identities (Edinburgh: Edinburgh University Press: 2018); Annamaria Motrescu-Mayes and Susan Aasman, Amateur Media and Participatory Cultures. Film, Video, and Digital Media (London-New York: Routledge 2019). On the relationship between amateur and institutional film practices see in particular Masha Salazkina and Enrique Fibla-Gutiérrez, eds, "Towards a Global History of Amateur Film Practices and Institutions," Film History: An International Journal, Vol. 30, no. 1 (Spring 2018). See also Masha Salazkina and Enrique Fibla-Gutiérrez' forthcoming edited collection Global Perspectives on Amateur Film. Histories and Cultures (Bloomington: Indiana University Press).

${ }^{4}$ Sarah Street, Joshua Yumibe, Chromatic Modernity. Color, Cinema, and Media of the 1920s (New York: Columbia University Press, 2019), 5.

${ }^{5}$ Arturo C. Quintavalle, ed., La bella addormentata. Morfologia e struttura del settimanale italiano (Parma: Università di Parma-Ist. Di Storia dell'Arte, 1972); Paola Pallottino, Storia dell'illustrazione italiana. Libri e periodici a figura dal XV al XX secolo (Zanichelli: Bologna, 1988); Fausto Colombo, ed., Libri giomali e riviste a Milano. Storia delle innovazioni nell'editoria milanese dall'Ottocento ad oggi (Milan: Abitare Segesta, 1998).

${ }^{6}$ It is possible to see the transition from black-and-white to colour of the Ferrania cover images at the following website, http://www.fondazione3m.it/page_rivistaferrania.php (last accessed April 22, 2020), in which there are the covers of some issues of the monthly magazine, along with the table of content.

7 Thierry Gervais and Gaëlle Morel, The Making of Visual News: A History of Photography in the Press (London: Bloomsbury, 2017). On colour in the news press see Kim Timby, "Look at those Lollipops! Integrating Color into News Pictures," in Jason E. Hill and Vanessa R. Schwartz, eds, Getting the Picture: The Visual Culture of the News (London-New York: Bloomsbury, 2015), 236-243. On the use of colour images in Life see Melissa Renn, "Life in Color: Life Magazine and the Color Reproduction of Works of Art," in Regina L. Blaszczyk, Uwe Spiekermann, eds, Bright Modernity. Color, Commerce, and Consumer Culture (London: Palgrave Macmillan, 2017), 167-188.

8 Augusto Sainati, "Stile e formato dell'informazione Incom," in Augusto Sainati, ed., La Settimana Incom. Cinegiornali e informazione negli anni '50 (Torino: Lindau, 2000), 32.

9 On Italian cinema and colour, see Federico Pierotti, Un'archeologia del colore nel cinema italiano. Dal Tecbnicolor ad Antonioni (Pisa: ETS, 2016).

${ }^{10}$ Orsola Silvestrini, "Il colore (non) viene dall'America. Documentari e film di animazione a colori in Italia (19351952)," in Alice Autelitano, Veronica Innocenti, Valentina Re, eds, I cinque sensi del cinema (Udine: Forum, 2005), 213. For the data and the analysis of the production of colour films in Italy see also Federico Pierotti, "Dalle 
invenzioni ai film. Il cinema italiano alla prova del colore (1930-59)," in Sandro Bernardi, ed., Svolte tecnologiche nel cinema italiano (Rome: Carocci, 2006), 85-139 and Orsola Silvestrini, "Tu vuò fà l'americano. La couleur dans le cinéma populaire italien," 1895. Mille buit cent quatre-vingt-quinze 55 (juin 2008): 25-51.

11 Aldo Grasso, Storia critica della televisione italiana 1954-1979 (Milan: Il Saggiatore, 2019).

${ }^{12}$ In 1954 - the first black-and-white programmes were broadcast in Italy - and the United States launched the first colour broadcasting with the NTSC (National Television System Committee) system. At first, the system did not work properly, and the acronym was sarcastically transformed in Never Twice Same Color, due to the chromatic instability. On the transition to colour in the US television system see Susan Murray, Bright Signals: A History of Color Television (Durham-London: Duke University Press, 2018). On Italian television's transition to colour see Gloria Gabrielli, "L'introduzione della televisione a colori in Italia 1962-1977," in Piero Melograni, ed., La paura della modernità. Opposizioni e resistenze allo sviluppo industriale (Rome: Cedis, 1987), 68-90, and Paola Valentini, "Società a colori: la televisione italiana e il passaggio al colore," in Maurizio Rossi and Andrea Siniscalco, eds, Colore e colorimetria. Contributi multidisciplinari, Vol. IX A (Santarcangelo di Romagna (RN): Maggioli, 2013), 856-863.

13 Peppino Ortoleva, Un ventennio a colori. Televisione privata e società in Italia, 1975-95 (Florence: Giunti, 1995); Giandomenico Crapis, Il frigorifero del cervello. Il Pci e la televisione da "Lascia o raddoppia?" alla battaglia contro gli spot (Rome: Editori Riuniti, 2002).

${ }^{14}$ The debate on the use of colour was also accompanied by the battle over the standards, that is a conflict between two different systems for the transmission of the signal, both technologically advanced: the German PAL (Phase Alternation Line) and the French SECAM (Séquentiel Couleur à Mémoire). Obviously, the choice also implied a precise political position: choosing one system or the other meant to stipulate political alliances with one of the two nations involved, see Andreas Fickers, "The Techno-politics of Colour: Britain and the European Struggle for a Colour Television Standard," Journal of British Cinema \& Television VII, n. 1 (April 2010): 95-114.

15 About the cultural meaning of colour in Western countries, see the works of Michel Pastoureau, like Dictionnaire des couleurs de notre temps. Symbolique et société (Paris: Bonneton, 1992). On the "fear of colour" in art history, see David Batchelor, Chromophobia (London: Reaktion, 2000).

${ }_{16}$ On amateur cinema in Italy see Luisella Farinotti and Elena Mosconi, eds, "Il metodo e la passione. Cinema amatoriale e film di famiglia in Italia," Comunicazioni sociali 3 (2005); Alice Cati, Pellicole di ricordi. Film di famiglia e memorie private (1926-1942) (Milan: Vita e Pensiero, 2009). On Italian female amateur filmmakers, see Sara Filippelli, Le donne e gli home movies. Il cinema di famiglia come scrittura del sé (Pisa: ETS, 2015).

${ }^{17}$ I analysed the how-to literature on amateur colour cinema in Elena Gipponi, "Fireworks and Carnivals: Applied and Natural Colours in Italian Home Movies," in Giovanna Fossati et al., eds, The Colour Fantastic: Chromatic Worlds of Silent Cinema (Amsterdam: Amsterdam University Press, 2018), 33-50.

18 This work's use of the term "modernity" refers to the process of consolidation of the cultural industry that occurred in Italy between the 1930s and the 1970s: creation of a truly mass audience, supremacy of the image over the word in all forms of communication, importation - mainly from the USA - of a large part of the cultural products. In particular, in the five years of the economic boom, modernity in Italy experienced a significant acceleration: at the turn between the 1950s and the 1960s there was a real modernisation within modernisation, David Forgacs, Italian Culture in the Industrial Era 1880-1980. Cultural Industries, Politics and the Public (ManchesterNew York: Manchester University Press, 1990).

${ }_{19}$ The most part of the amateur filmmakers that I interviewed, when asked about the reasons why they chose colour instead of black-and-white for their home movies, answered that, since colour films were available, they "obviously" bought colour films, abandoning black-and-white (but not for photography, photographs were still shot preferably in black-and-white: "I liked it better", is a recurring declaration).

${ }^{20}$ Federico Pierotti, "Il catalogo è questo. Fonti per la storia del documentario a colori in Italia nel secondo dopoguerra." in Alice Autelitano and Valentina Re, eds, Il racconto del film / Narrating the Film (Udine: Forum, 2006), 61-62.

${ }^{21}$ Ivi, 62 .

${ }^{22}$ The notation of the reels is the one adopted by Home Movies to catalogue the archival fund.

${ }^{23}$ This technique, that is "the shooting of a monument or of a landscape, [...] filmed literally through photographs and postcards" is a recurring one in colour short documentaries, thus demonstrating once more the mediocrity and the limited economic resources of these "professional" productions. Analogously, the "four seasons" is another frequent subject of the Italian colour documentary of the 1950s, Ibid.

24 "The amateur filmmaker is a concretely active spectator, a spectator who thinks of him/herself as a producer and becomes a producer, while also remaining a spectator. Without any doubt, he/she still likes to watch films in a dark screening room, but for him/her, cinema doesn't end in that room. The cinematic screening is just one of the possible forms of cinema as a dispositif, is one of the nodes of a network of instruments and practices that contain cinema into a more extended concrete and imaginary totality" [my translation], Valérie Vignaux and Benoît 
Turquety, eds, L'amateur en cinéma. Un autre paradigme. Histoire, esthétique, marges et institutions (Paris: AFRHC, 2016), 17.

${ }_{25}$ Curiously, the institutional cinema with its genres is the acknowledged reference for the production of blackand-white amateur fiction films. By way of example, in the works of Ignazio De Falco (consulted thanks to a personal contact, since they are not archived at Home Movies) there is an unrefined fiction film, one of the few black-and-white works in a $8 \mathrm{~mm}$ collection that otherwise is almost entirely constituted of colour films. The film is called Winston 7 ricevuto, is dated 1957 and is a crime/noir with a basic detection plot. The choice of black-andwhite film is intentional, and it is compliant with a precise expressive strategy: "Giallo can only be shot in black and white", the author himself has declared.

${ }^{26}$ Richard Misek, Chromatic Cinema. A History of Screen Color (Malden, MA-Oxford: Wiley-Blackwell, 2010 ), 83-84. On cinema and colour, see also the two volumes by Jacques Aumont, Introduction à la couleur: des discours aux images (Paris: Armand Colin, 1994), and Jacques Aumont, ed., La couleur en cinéma (Paris-Milan: Cinémathèque française/Musée du cinéma/Fondazione Mazzotta, 1995).

${ }^{27} \mathrm{Ivi}, 84$.

\section{Bibliography}

Aasman, Susan, Andreas Fickers and Joseph Wachelder, eds. Materializing Memories. Dispositifs, Generations, Amateurs. New York-London: Bloomsbury 2018.

Aumont, Jacques. Introduction à la couleur: des discours aux images. Paris: Armand Colin, 1994.

Aumont, Jacques, ed. La couleur en cinéma. Paris-Milan: Cinémathèque française/Musée du cinéma/Fondazione Mazzotta, 1995.

Batchelor, David. Chromophobia. London: Reaktion, 2000.

Cati, Alice. Pellicole di ricordi. Film di famiglia e memorie private (1926-1942). Milan: Vita e Pensiero, 2009.

Colombo, Fausto, ed. Libri giornali e riviste a Milano. Storia delle innovarioni nell'editoria milanese dall'Ottocento ad oggi. Milan: Abitare Segesta, 1998.

Crapis, Giandomenico. Il frigorifero del cervello. Il Pci e la televisione da "Lascia o raddoppia?" alla battaglia contro gli spot. Rome: Editori Riuniti, 2002.

Enticknap, Leo. Moving Image Technology: From Zoetrope to Digital. London-New York: Wallflower Press, 2005.

Farinotti, Luisella and Elena Mosconi, eds. "Il metodo e la passione. Cinema amatoriale e film di famiglia in Italia." Comunicazioni sociali 3 (2005).

Fickers, Andreas. "The Techno-politics of Colour: Britain and the European Struggle for a Colour Television Standard.” Journal of British Cinema \& Television VII, n. 1 (April 2010): 95-114.

Filippelli, Sara. Le donne e gli home movies. Il cinema di famiglia come scrittura del sé. Pisa: ETS, 2015.

Forgacs, David. Italian Culture in the Industrial Era 1880-1980. Cultural Industries, Politics and the Public. Manchester-New York: Manchester University Press, 1990.

Gabrielli, Gloria. “L'introduzione della televisione a colori in Italia 1962-1977.” In Melograni, Piero, ed. La paura della modernità. Opposizioni e resistenze allo sviluppo industriale. Rome: Cedis, 1987.

Gervais, Thierry and Gaëlle Morel. The Making of V isual News: A History of Photography in the Press. London: Bloomsbury, 2017.

Gipponi, Elena. "Fireworks and Carnivals: Applied and Natural Colours in Italian Home Movies." In Fossati, Giovanna et al., eds. The Colour Fantastic: Chromatic Worlds of Silent Cinema. Amsterdam: Amsterdam University Press, 2018.

Grasso, Aldo. Storia critica della televisione italiana 1954-1979. Milan: Il Saggiatore, 2019.

Harris, Neil. Cultural Excursions: Marketing Appetites and Cultural Tastes in Modern America. Chicago-London: University of Chicago Press, 1990.

Misek, Richard. Chromatic Cinema. A History of Screen Color. Malden, MA-Oxford: Wiley-Blackwell, 2010. 
Motrescu-Mayes, Annamaria and Heather Norris Nicholson. British Women Amateur Filmmakers. National Memories and Global Identities. Edinburgh: Edinburgh University Press: 2018.

Motrescu-Mayes, Annamaria and Susan Aasman. Amateur Media and Participatory Cultures. Film, Video, and Digital Media. London-New York: Routledge 2019.

Murray, Susan. Bright Signals: A History of Color Television. Durham-London: Duke University Press, 2018.

Neale, Steve. Cinema and Technology: Image, Sound, Color. London: Basingstoke-Macmillan Education, 1985.

Norris Nicholson, Heather. Amateur Film. Meaning and Practice 1927-77. Manchester-New York: Manchester University Press, 2012.

Ortoleva, Peppino. Un ventennio a colori. Televisione privata e società in Italia, 1975-95. Florence: Giunti, 1995. Pallottino, Paola. Storia dellillustrazione italiana. Libri e periodici a figura dal XV al XX secolo. Zanichelli: Bologna, 1988.

Pastoureau, Michel. Dictionnaire des couleurs de notre temps. Symbolique et société. Paris: Bonneton, 1992.

Pierotti, Federico. "Dalle invenzioni ai film. Il cinema italiano alla prova del colore (1930-59)." In Bernardi, Sandro, ed. Svolte tecnologiche nel cinema italiano. Rome: Carocci, 2006.

Pierotti, Federico. "Il catalogo è questo. Fonti per la storia del documentario a colori in Italia nel secondo dopoguerra." In Autelitano, Alice and Valentina Re, eds. Il racconto del film / Narrating the Film. Udine: Forum, 2006.

Pierotti, Federico. Un'archeologia del colore nel cinema italiano. Dal Technicolor ad Antonioni. Pisa: ETS, 2016.

Quintavalle, Arturo C., ed. La bella addormentata. Morfologia e struttura del settimanale italiano. Parma: Università di Parma-Ist. Di Storia dell'Arte, 1972.

Rascaroli, Laura and Gwenda Young with Barry Monahan, eds. Amateur Filmmaking. The Home Movie, the Archive, the Web. New York-London: Bloomsbury 2014.

Renn, Melissa. "Life in Color: Life Magazine and the Color Reproduction of Works of Art." In Blaszczyk, Regina L. and Uwe Spiekermann, eds. Bright Modernity. Color, Commerce, and Consumer Culture. London: Palgrave Macmillan, 2017.

Salazkina, Masha and Enrique Fibla-Gutiérrez, eds. "Towards a Global History of Amateur Film Practices and Institutions." Film History: An International Journal. Vol. 30. no. 1 (Spring 2018).

Sainati, Augusto. "Stile e formato dell'informazione Incom." In Sainati, Augusto, ed. La Settimana Incom. Cinegiornali e informazione negli anni '50. Torino: Lindau, 2000.

Shand, Ryan and Ian Craven, eds. Small-Gauge Storytelling. Discovering the Amateur Fiction Film. Edinburgh: Edinburgh University Press, 2013.

Silvestrini, Orsola. "Il colore (non) viene dall'America. Documentari e film di animazione a colori in Italia (1935-1952)." In Autelitano, Alice, Veronica Innocenti, Valentina Re, eds. I cinque sensi del cinema. Udine: Forum, 2005.

Silvestrini, Orsola. “Tu vuò fà l'americano. La couleur dans le cinéma populaire italien.” 1895. Mille buit cent quatre-vingt-quinze 55 (juin 2008): 25-51.

Street, Sarah and Joshua Yumibe. Chromatic Modernity. Color, Cinema, and Media of the 1920s. New York: Columbia University Press, 2019.

Tepperman, Charles. Amateur Cinema. The Rise of North American Moviemaking, 1923-1950. Oakland: University of California Press, 2015.

Timby, Kim. "Look at those Lollipops! Integrating Color into News Pictures." In Hill, Jason E. and Vanessa R. Schwartz, eds. Getting the Picture: The Visual Culture of the News. London-New York: Bloomsbury, 2015.

Valentini, Paola. “Società a colori: la televisione italiana e il passaggio al colore." In Rossi, Maurizio and Andrea Siniscalco, eds. Colore e colorimetria. Contributi multidisciplinari, Vol. IX A. Santarcangelo di Romagna (RN): Maggioli, 2013. 
Vignaux, Valérie and Benoît Turquety, eds. L'amateur en cinéma. Un autre paradigme. Histoire, esthétique, marges et institutions. Paris: AFRHC, 2016.

\section{About the Author}

Elena Gipponi is a postdoctoral fellow at IULM University of Milan, where she received her PhD in "Communication and New Technologies". Since 2008, she collaborates to IULM's courses of History of Cinema. She has edited with Joshua Yumibe "Cinema and Mid-Century Colour Culture", a special issue of Cinéma \& Cie. International Film Studies Journal (n. 32, Spring 2019). Her first book, Una rivoluqione inavvertita. Dal bianco e nero al colore nello scenario mediale della modernità italiana, has been published in Italy by Mimesis (2020). 